served by examining Caspar David Friedrich's "Gebüsch im Schnee" (1828) by means of external PIXE and a supplementary cross-section study. The intermediate layer of white lead explains the generally observed pure contrasts of X-ray photographs taken from paintings of Caspar David Friedrich [7].

The information depth, i.e., the maximum depth where characteristic radiation (X-, $\gamma$, p) is produced and reaches the corresponding detector, depends on both the stopping of the primary proton beam and the absorption of the $\mathrm{X}$ - and $\gamma$-rays or the stopping of the protons after backscattering, respectively. For the layer structure as given by the microscope results (Fig. 2), the calculated range of 4-MeV protons amounts to approximately $135 \mu \mathrm{m}$. Consequently, the chalk ground layer is outside the information depth and the $\mathrm{Ca}-\mathrm{K}$ radiation in the PIXE spectrum (Fig. 1) originates from $\mathrm{Ca}$ portions in the film containing white lead and probably additionally from $\mathrm{Ca}$ traces within the varnish. The varnish layer (supposed as $\mathrm{C}_{30} \mathrm{H}_{50} \mathrm{O}_{2}$ ) of about $100 \mu \mathrm{m}$ thickness contributes strongly to the proton energy $\operatorname{loss}\left(\Delta E_{\mathrm{p}} \approx 2.3 \mathrm{MeV}\right)$. However, the attenuation of the $\mathrm{Ca}-\mathrm{K}$ radiation through such a thick layer is relatively weak $\left(\Delta Y_{\mathrm{x}}<50 \%\right)$. With increasing $\mathrm{X}$-ray energy ( $\mathrm{Fe}-\mathrm{K}, \mathrm{Pb}-\mathrm{L}$ radiation) intensity losses due to absorption further decrease. In conclusion, the present PIXE/PIGE equipment at the external proton-beam facility is now being extended by external RBS for depth-dependent studies of pure thin pigment layers and very near-surface analysis of oil paintings, including varnish layers, and a quick discrete $E_{\mathrm{p}}$-variation system to change the information depth in PIXE/PIGE examinations of the medium depth regions.
Received June 14, 1994

1. Schramm, H.-P., Hering, B.: Historische Malmaterialien und ihre Identifizierung. Graz: ADVA 1989

2. Amsel, G, Heitz, Ch., Menu, M.: Nucl. Inst. Meth. B]4, 30 (1986)

3. Richter, F.W.: ibid. B3, 105 (1984)

4. Anttila, A., Hänninen, R., Räisänen, J.: J. Radioanal. Chem. 62, 293 (1981)

5. Chu, W.-K., Mayer, J.W., Nicolet, M.-A.: Backscattering Spectrometry. New York: Academic Press 1978

6. Schramm, H..P., Neelmeijer, C., Matthes, H., Pfestorf, W.: Wiener Ber. Naturwiss. Kunst 4/5, 26 (1987/88)

7. Sandner, I., Schramm, H.-P., in: K. Wettengel: Caspar David Friedrich, Winterlandschaften, S. 75. Museum für Kunst- und Kulturgeschichte Dortmund, Edition Braus 1990

\title{
Correlating the Holocene Records: Icelandic Tephra Found in Schleswig-Holstein (Northern Germany)*
}

\author{
C. van den Bogaard \\ GEOMAR Forschungszentrum für marine Geowissenschaften, D-24148 Kiel \\ W. Dörfler \\ Institut für Ur- und Frühgeschichte der Universität, D-24098 Kiel \\ P. Sandgren \\ Department of Quaternary Geology, S-22363 Lund

\section{H.-U. Schmincke} \\ GEOMAR Forschungszentrum für marine Geowissenschaften, D-24148 Kiel
}

Widespread tephra layers result from major explosive volcanic eruptions. They form areally extensive isochronous marker horizons, and allow a high-resolution stratigraphic correlation of peat, lake, onshore and offshore sediments. If the age of an eruption is known, its ash layer also permits very precise dating of the enclos-

* This study was supported by the Bundesministerium für Forschung und Technologie (BMFT), core program "Einsatz neuer Technologien in den Geisteswissenschaften". ing sediments. Combined with palynological and archaeological studies, tephra layers thus enable detailed reconstructions of the vegetation, climate, and settlement history in prehistoric times. Distinct ash layers are known to occur in Late Pleistocene and Holocene strata throughout the North Atlantic [1], Scotland [2], Ireland [3], Scandinavia [4-7], and northern Germany [8,9]. With one exception, these tephra layers resulted from volcanic eruptions in Iceland. The exception is the Laacher See tephra, a well-established tephra marker horizon in northern Germany, Sweden, and Switzerland, which erupted from the Laacher See volcano (East Eifel Volcanic Field, Germany) during the Late Glacial Allerød period ca. 11000 to 11300 B.P. $\left([9,10]\right.$; uncalibrated ${ }^{14} \mathrm{C}$ AMS age from [11]). Here, we report on a volcanic ash layer from the Dosenmoor in SchleswigHolstein (northern Germany, Fig. 1) which can be correlated with a distinct Holocene eruption in Iceland. This ash layer is likely to form an important isochronous marker in the Late Quaternary to prehistoric palynological record of northern and central Europe.

The Dosenmoor is a raised bog $2.7 \mathrm{~km}$ in diameter. Drill cores from the center of the bog consist of $6.3 \mathrm{~m}$ raised bog peat, $1.2 \mathrm{~m}$ fen peat, and $0.6 \mathrm{~m}$ organic mud overlying minerogenic mud. The mineral content of the peat is generally very low, since peat in a raised bog can only receive airborne mineral matter (including iron compounds), and is only weakly influenced by soil erosion from higher areas surrounding the bog. We have studied the Dosenmoor core with respect to its pollen record, isothermal remanent magnetization, conventional radiocarbon ages, and volcanic ash content. 


\section{Age Depth Stratigraphy Magnetic profile [a BP] [cm] \& pollen zones SIRM $\left[\mathrm{mAm}^{2} / \mathrm{kg}\right]$}

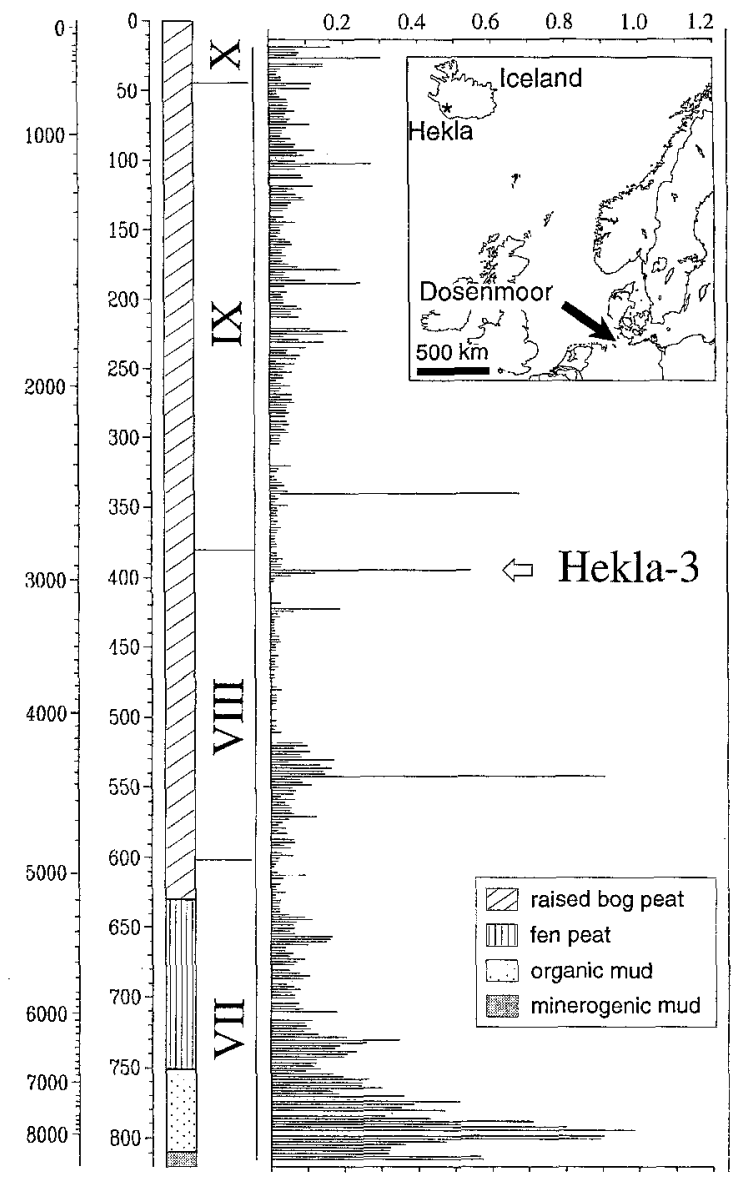

range from 73.0 to $66.0 \mathrm{wt} \%, \mathrm{~K}_{2} \mathrm{O}$ from 2.6 to $2.0 \mathrm{wt} \%$, and $\mathrm{Na}_{2} \mathrm{O}$ from 4.5 to $3.3 \mathrm{wt} \%$ (Fig. 2), indicating a compositionally zoned eruption.

The Dosenmoor ash differs drastically from the older Laacher See tephra, which has a phonolitic composition with high alkali contents $(14-16 \mathrm{wt} \%)$ and relatively low silica contents $(57-61 \mathrm{wt} \%$; Fig. 2), excluding the Laacher See volcano as a source of the Dosenmoor ash. The bimodal rhyolitic and basaltic Vedde ash (10600 B.P. [4]) is much older than the Dosenmoor tephra and contains glass shards with either higher or lower $\mathrm{SiO}_{2}$ contents. The Saksunarvatn ash (9100 B.P. [7]), which has recently been detected in several localities in northern Germany [8], is tholeiitic in composition, and also older than the Dosenmoor tephra.

The silica and alkali contents of the Dosenmoor ash are most compatible with ash layers from the Hekla volcano (Iceland), the main northern hemisphere

Fig. 1. Location of the Dosenmoor peat bog in Schleswig-Holstein (Germany). Stratigraphy, uncalibrated ${ }^{14} \mathrm{C}$ age scale, and pollen zones versus isothermal remanent magnetization profile (SIRM)
Preliminary palynological results indicate that the core represents pollen zones VII to $\mathrm{X}$ (according to [12]), and 22 radiocarbon ages, determined at the ${ }^{14} \mathrm{C}$ laboratory of the University of Kiel, show that the drilled section comprises an age interval of approximately 8000 years. In order to determine the concentration of iron oxides in the core, the entire section was contiguously subsampled in weakly paramagnetic polystyrene boxes at $2-\mathrm{cm}$ intervals. The saturation isothermal remanent magnetization (SIRM) was then measured in a field of 1 Tesla, applying a Redcliff pulse magnetic charger and a Molspin Minispin spinner magnetometer. The dry weight of all samples was determined to allow the calculation of mass-specific SIRM.

The results of the SIRM analyses, radiocarbon age determinations, and pollen analyses are shown in Fig. 1. In the fen peat and the overlying raised bog peat, SIRM values are typically $<0.2-0.1$ $m \mathrm{Am}^{2} \mathrm{~kg}^{-1}$. The small SIRM variations in these two stratigraphic units probably result from long-distance airborne minerogenic matter. Apart from these generally low values, three significant peaks can be seen at 340,395, and $545 \mathrm{~cm}$, the interpolated ${ }^{14} \mathrm{C}$ age of the peak at depth $395 \mathrm{~cm}$ (ca. 3000 B.P.), roughly coinciding with a major known Plinian eruption of the Hekla volcano, Iceland. We therefore sampled $6 \mathrm{~cm}^{3}$ of the peat core at $2-\mathrm{cm}$ distances from $6 \mathrm{~cm}$ above to $6 \mathrm{~cm}$ below this stratigraphic position and dissolved the samples in $\mathrm{H}_{2} \mathrm{SO}_{4}$ and $\mathrm{HNO}_{3}$, effectively removing $>99 \%$ of the organic matter.

Polished thin sections of grain mounts from the mineral residues were studied by transmission microscope and electron microprobe. Samples from 394 to $400 \mathrm{~cm}$ depth contain abundant colorless, highly vesicular pumice and bubble wall glass shards, mostly $<80 \mu \mathrm{m}$ in diameter. Electron microprobe analyses of 24 shards show rhyolitic to rhyodacitic compositions with totals $>97 \%$. $^{2} \mathrm{SiO}_{2}$ contents
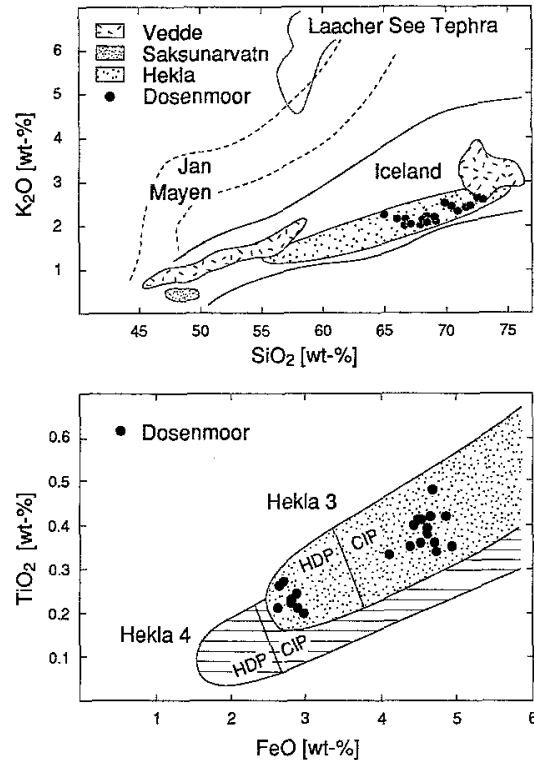

Fig. 2. Composition of Dosenmoor ash glass shards compared to known Late Quaternary volcanic eruptions in northern Europe. Top: $\mathrm{SiO}_{2}$ versus $\mathrm{K}_{2} \mathrm{O}$ reference plot modified from [4], Laacher See data from [9], Saksunarvatn composition from [8]. Hekla field comprises the major known Plinian eruptions of Hekla (H1, H3, H4, H5). Bottom: Fields of Hekla 4 and Hekla 3 glass shard compositions ( $n=120$ ) compared to Dosenmoor glass shard compositions $(n=24)$ in the $\mathrm{FeO}$ versus $\mathrm{TiO}_{2}$ variation diagram. $H D P$ highly differentiated Plinian eruptive phases, CIP compositionally intermediate Plinian eruptive phases 
source of explosive silicic eruptions in the time interval studied, with major eruptions at ca. 4000 B.P. (Hekla 4 [13]), 3840 B.P. (Hekla 4 [14]), and 2800 B. P. (Hekla 3 [13]), among others. Both eruptions, Hekla 4 and Hekla 3, are strongly compositionally zoned, with complex eruption mechanisms: Following an initial phreatomagmatic phase (H4), a major volume of highly evolved rhyolite was erupted in high Plinian eruptions, resulting in widespread fallout deposits [14]. The latter are the eruption phases most likely to have produced distal fallout ash. Hekla 4 magma compositions at this stage are significantly more silica-rich (73 to $75 \mathrm{wt} \% \mathrm{SiO}_{2}$ ) than equivalent eruptive phases of Hekla 3 [15]. Both eruptions terminated with dacitic to andesitic magmas, erupted in lower eruption columns. Microprobe analyses of Hekla 4, Hekla 3, and Dosenmoor glass shards using identical instrumental settings (Cameca SX50, $15 \mathrm{kV}, 6 \mathrm{nA}, 12 \mu \mathrm{m}$ beam diameter) show all EMP data of the Dosenmoor to plot within the compositional fields of the Hekla 3 Plinian eruptive phase, which partly overlap with late-erupted Hekla 4 magmas (H4-CIP; Fig. 2). However, none of the glass shards studied shows the extremely high $\mathrm{SiO}_{2}$ - and low $\mathrm{FeO}$ - and $\mathrm{TiO}_{2}$-values typical for the most evolved Hekla 4 Plinian eruptive phase (H4-HDP).

The Dosenmoor ash is therefore interpreted to represent part of the Hekla 3 tephra blanket, which resulted from an explosive eruption of Hekla volcano at 2800 B.P. The ${ }^{14} \mathrm{C}$ ages of the enclosing sediments $(3470 \pm 50$ B.P. at $445-450 \mathrm{~cm}$ depth and $2810 \pm 47$ B.P. at $381-385 \mathrm{~cm}$ depth) are fully compatible with this interpretation.

Our study indicates that SIRM measurements provide an excellent potential means to detect volcanic ash in peat cores that is too dispersed or faint to show up macroscopically. The combination of chemical fingerprinting by microprobe methods and ${ }^{14} \mathrm{C}$ dating of bracketing organic sediments allow the unequivocal identification of a well-known Holocene tephra layer from Iceland $(\mathrm{H} 3)$ which erupted during the Younger Bronze Age. In the pollen stratigraphy, the $\mathrm{H} 3$ level predates the shift from the subboreal to the subatlantic climate (zones IX/VIII) and is located just between the increase in beech (Fagus) to ca. $2 \%$ of the tree sum and the hazel (Corylus) maximum. Our study also sheds new light on the areal distribution of Hekla ash layers, which appears to be much more extensive than previously thought, i.e., indicating that the erupted magma volume of Hekla 3 may have been much larger than $2.2 \mathrm{~km}^{3}$ DRE [13], and possibly explaining the significant climatic and environmental impact of this eruption, as deduced from tree-ring studies and acidity layers in ice cores $[16,17]$. We will continue our study to trace Hekla 3 and possibly other tephra layers in Holocene deposits in northern Germany. Most probably, the other two peaks in the Dosenmoor SIRM profile also reflect volcanic ash layers.

The magnetic analyses were carried out at the palaeomagnetic laboratory at the Geological Institute in Lund, Sweden. We thank Prof. H. Willkomm (Kiel University) for providing unpublished ${ }^{14} \mathrm{C}$ data, $\mathrm{J}$.
Freitag (Geomar) for helping with the EMP analyses, and P.v.d. Bogaard (Geomar) for critically reviewing earlier versions of the manuscript.

Received July 14, 1994

1. Kvamme, T., Mangerud, J., Furnes, H., Ruddimann, W.F.: Norsk Geol. Tidsskr. 69, 251 (1989)

2. Dugmore, A.: Geogr. Mag. 105, 168 (1989)

3. Hall, V.A., Pilcher, J.R., McCormac, F. G.: New Phytol. 125, 10 (1993)

4. Mangerud, J., Lie, S.E., Furnes, H., Kristiansen, I.L., Lomo, L.: Quat. Res. 21, 85 (1984)

5. Persson, C.: Sveriges Geol. Undersök. C656, 1 (1971)

6. Thorarinsson, S.: Geogr. Ann. $63 A, 109$ (1981)

7. Mangerud, J., Furnes, H., Johansen, J.: Quat. Res. 26, 262 (1986)

8. Merkt, J., Müller, H., Knabe, W., Müller, P., Weiser, T.: Boreas 22, 93 (1993)

9. Bogaard, v.d. P., Schmincke, H.-U.: Geol. Soc. Am. Bull. 96, 1554 (1985)

10. Bogaard, v.d. P., Schmincke, H.-U., Freundt, A., Park, C., in: Thera and the Aegean World III, Vol. 2 (D.A. Hardy, ed.). London: Thera Foundation 1990

11. Hajdas-Skowronek, I.: Dissertation ETH Zürich 1993

12. Firbas, F.: Nacheiszeitliche Waldgeschichte Mitteleuropas, nördlich der Alpen, 480, Band I. Jena 1949

13. Larsen, G., Thorarinsson, S.: Jökull 27, 28 (1977)

14. Hall, V.A., Pilcher, J.R., McCormac, F. G.: Holocene 4, 79 (1994)

15. Annertz, K., Nilsson, M., Sigvaldason, G.E.: Nordic Volc. Instit. 8503 (1985)

16. Baillie, M.G.L.: Endeavour 13(2), 78 (1989)

17. Hammer, C.U., Clausen, H.B., Dansgaard, W.: Nature 288, 230 (1980)

\section{Infrared Stimulated Luminescence: Dating Tool for Archaeosediments *}

\section{H. Wiggenhorn, A. Lang, and G. A. Wagner \\ Forschungsstelle Archäometrie der Heidelberger Akademie der Wissenschaften, MPI für Kernphysik, D-69117 Heidelberg}

\footnotetext{
* This study was supported by the Bundesministerium für Forschung und Technologie (BMFT), core program "Einsatz neuer Technologien in den Geisteswissenschaften".
}

Thermoluminescence (TL) is a wellknown method for dating archaeological materials and sediments. It exploits the fact that energy from ambient natural radioactivity and cosmic radiation is stored as accumulated dose (AD) in minerals. Charges, produced by the ionizing radiation, are trapped at metastable energy levels of crystal defects situated between the valence and conduction band. These charges are released again either by heat (e.g., firing of ceramics) or by light (bleaching of sediments during transportation and deposition), thus resetting the "clock". In TL dating, AD is determined by heating the mineral samples to 